\title{
Outcomes of Percutaneous Nephrolithotomy in Patients with Anomalous Kidney
}

\author{
Anomalili Böbreği Olan Hastalarda Perkütan Nefrolitotomi Sonuçlarımız
}

\author{
Mehmet Yoldaş1, Cemal Selçuk İşoğlu2, Tufan Süelözgen3, Hakan Türk1, Mustafa Karabıçak3, Batuhan Ergani3, Hayal Boyacıoğlu4, \\ Yusuf Özlem İlbey3 \\ ${ }^{1}$ Dumlupınar University, Kütahya Evliya Çelebi Training and Research Hospital, Department of Urology, Izmir, Turkiye \\ 2Hakkari Public Hospital, Clinic of Urology, Hakkari, Turkiye \\ 3 University of Health Sciences, Tepecik Training and Research Hospital, Clinic of Urology, Izmir, Turkiye \\ ${ }^{4}$ Ege University Faculty of Science, Department of Statistics, Izmir, Turkiye
}

What's known on the subject? and What does the study add?

There are limited studies related to percutaneous nephrolithotomy in the anomalous kidney. So we decided to share our results by scanning our patient data retrospectively.

\begin{abstract}
Objective: To evaluate the success and complication rate of percutaneous nephrolithotomy (PNL) performed in patients with congenital anomalies such as horseshoe kidneys, crossed renal ectopia and renal malrotation.

Materials and Methods: Data of 1472 patients who underwent PNL operation in our clinic between January 2007 and January 2015 were analyzed retrospectively. PNL was performed in 28 renal units of 26 patients with congenital renal anomalies. Demographic data of the patients, type of congenital renal anomalies, success rate of PNL and complications were evaluated.

Results: Out of 28 PNL-performed renal units, 14 were found out to be with fusion and 14 with rotation anomalies. The average age of the patients was $53( \pm 1.97)$ years, 19 were male and 7 were female with an average stone size of $515( \pm 87.4) \mathrm{mm}^{2}$. The average operating time was $109( \pm 11.0)$ minutes and fluoroscopy time was $191( \pm 48.4)$ seconds. The stone-free rate detected postoperatively by computed tomography was $55 \%$. Complications included postoperative fever in 3 patients, postoperative arteriovenous fistula in 1 patient, and intraoperative colon injury in 1 patient.
\end{abstract}

Conclusion: PNL is a safe and effective method in the treatment of stones in kidneys with congenital anomalies.

Keywords: Anomalous kidneys, complication, percutaneous nephrolithotomy

\section{$\ddot{0 z}$}

Amaç: Atnalı böbrek, crossed renal ektopi ve böbrek malrotasyonu gibi anomalili böbreği olan hastalarda yapılan perkütan nefrolitotomi (PNL) sonuçlarını ve komplikasyonlarını değerlendirmek amaçlandı.

Gereç ve Yöntem: Ocak 2007 ve Şubat 2015 yılları arasında kliniğimizde PNL yapılan 1472 hastanın verileri retrospektif olarak incelendi. Böbrek anomalisi olan 26 hasta ve toplamda 28 renal üniteye PNL yapıldı. Hastaların demografik verileri, konjenital anomalinin tipi, PNL başarıSı ve komplikasyonlar değerlendirildi.

Bulgular: Opere edilen 28 renal ünitenin 14 tanesinde füzyon, 14 tanesinde ise rotasyon anomalisi vardı. Hastaların ortalama yaşı $53( \pm 1,97)$ yıldı. Hastaların 19 tanesi erkek, 7 tanesi kadındı ve ortalama taş boyutu $515( \pm 87,4) \mathrm{mm}^{2}$ olarak hesaplandı. Ortalama operasyon zamanı 109 $( \pm 11,0)$ dakika ve floroskopi süresi ise $191( \pm 48,4)$ saniyeydi. Postoperatif istenen bilgisayarlı tomografide $\% 55$ taşsızlık saptandı. Komplikasyon olarak ise 1 hastada intraoperatif kolon yaralanması, 3 hastada ateş yüksekliği ve 1 hastada arteriyovenöz fistül gözlendi.

Sonuç: Konjenital anomalili böbrek taşı tedavisinde PNL güvenli ve başarılı bir yöntemdir.

Anahtar Kelimeler: Anomalili böbrek, komplikasyon, perkütan nefrolitotomi

Correspondence: Cemal Selçuk İşoğlu MD, Hakkari Public Hospital, Clinic of Urology, Hakkari, Turkiye

Phone: +90 5462421560 E-mail: selcukisoglu@hotmail.com ORCID ID: orcid.org/0000-0002-9999-3908

Received: 14.04.2017 Accepted: 08.08.2017

Cite this article as: Yoldaş M, İşoğlu CS, Süelözgen T, Türk H, Karabıçak M, Ergani B, Boyacıoğlu H, İlbey YÖ. Outcomes of Percutaneous Nephrolithotomy in Patients with Anomalous Kidney. J Urol Surg 2017;4:167-170. 


\section{Introduction}

Clinical approach to kidney stones in abnormal kidneys is regarded as a specific and difficult case in urology practice. Percutaneous nephrolithotomy (PNL) is the gold standard treatment method for kidney stones larger than $2 \mathrm{~cm}$ (1). However, it is not established yet for stones that occur in rare cases such as horseshoe kidney, renal malrotation, crossed renal ectopia, and pelvic kidneys.

As for patients with a kidney anomaly, the goal of the treatment for kidney stones is to render the patient free of stone with highest treatment performance and lowest complication rates, as it is for kidneys with normal anatomy. In this study, we evaluated the success rates and complications of PNL that we performed in patients with renal anomalies.

\section{Materials and Methods}

A total of 1472 patients, who underwent PNL in our clinic between January 2007 and January 2015, were retrospectively analysed. A total of 26 patients with renal abnormalities (28 renal units) whose data were appropriate and complete were included in the study. Of these, PNL was performed in 14 renal units with fusion anomaly (13 horseshoe kidney, 1 crossed renal ectopia with fusion) and in 14 renal units with rotation anomaly.

All patients were evaluated with non-contrast abdominal computed tomography (CT) preoperatively and informed consent was obtained from patients before the surgery.

\section{Surgical Procedure}

Complete blood count, biochemical tests, coagulation tests and urine culture were performed in all patients preoperatively. Appropriate antibiotic treatment was given to patients with positive urinary cultures and they were operated when they had sterile urine cultures. The patient was placed in the prone position after a 6 Fr open-ended catheter was inserted through the urethra via cystoscopy while in the lithotomy position. The procedure was performed under general anesthesia. Following the injection of a contrast agent via the urethral catheter, an access needle was introduced into the renal collecting system through the appropriate calyx under fluoroscopic guidance. After placement of the guiding catheter, the Amplatz dilator set was used in order to create the tract, first with a 6 Fr dilator followed by a 28-30 Fr dilator, using the single step method. If necessary, a second access was created with the same method. The stones were removed by using a $24 \mathrm{Fr}$ nephroscope and an ultrasonic lithotripter. A $14 \mathrm{Fr}$ re-entry Malecot catheter was routinely inserted after the operation was terminated. The stone-free status of the patients was evaluated 1 month after surgery with non-contrast abdominal CT.

\section{Results}

The average age of the patients was $53( \pm 1.97)$ years; 19 were male and 7 were female. Of patients with horseshoe kidney anomaly, 5 had stones in the right kidney, 3 in the left kidney, and 4 in both kidneys. Among 4 patients with bilateral kidney stones, PNL operation was performed only in one patient in different sessions. Of patients with rotational kidney anomaly, 7 had stones in the left kidney, 6 in the right kidney, and 1 in both kidneys. For patient with rotation anomaly and bilateral kidney stones, PNL was performed in the left kidney and extracorporeal shock wave lithotripsy in the right kidney. The average stone size in 2 dimensional measurements was $812.5 \mathrm{~mm}^{2}$ in kidneys with horseshoe abnormalities while it was $600 \mathrm{~mm}^{2}$ in kidneys with rotational abnormalities and $300 \mathrm{~mm}^{2}$ in crossed renal ectopia (Table 1).

Access was achieved to the stones in anomalous kidneys by a single access in 21 of 28 renal units and by double access in 7 renal units, out of which 3 had horseshoe anomaly and 4 had rotational anomaly. Out of 10 kidneys with horseshoe anomaly, 5 single intercostal accesses were performed in the upper calyx group of the kidney. In one patient with crossed fused renal ectopia, single subcostal access to mid-calyx group was performed. Single access was performed to 10 out of 14 kidneys with rotation anomaly; namely 5 subcostal accesses to mid-calyx group, 4 subcostal accesses to upper calyx group and 1 intercostal access to upper calyx group (Table 2).

Table 1. Characteristics of the patients

\begin{tabular}{|c|c|c|c|c|}
\hline Renal anomaly & $\begin{array}{l}\text { Horseshoe } \\
\text { kidney }\end{array}$ & $\begin{array}{l}\text { Crossed } \\
\text { renal } \\
\text { ectopia }\end{array}$ & $\begin{array}{l}\text { Rotational } \\
\text { anomaly }\end{array}$ & Total \\
\hline Renal units (n) & 13 & 1 & 14 & 28 \\
\hline Age & 53.5 & 55 & 50.5 & $53( \pm 1.97)$ \\
\hline \multicolumn{5}{|l|}{ Gender (n) } \\
\hline Female & & & 8 & 7 \\
\hline Male & 13 & 1 & 6 & 19 \\
\hline \multicolumn{5}{|l|}{ Side of stone (n) } \\
\hline Left & 3 & 1 & 7 & 11 \\
\hline Right & 5 & & 6 & 11 \\
\hline Bilateral & 5 & & 1 & 6 \\
\hline $\begin{array}{l}\text { Average size } \\
\text { of the stone }\left(\mathrm{mm}^{2}\right)\end{array}$ & 812.5 & 300 & 600 & $515( \pm 87.4)$ \\
\hline \multicolumn{5}{|l|}{$\begin{array}{l}\text { Localization of } \\
\text { the stone }\end{array}$} \\
\hline Pelvis & 5 & & 5 & 10 \\
\hline Calyces & & 1 & 4 & 5 \\
\hline Pelvis and calyces & 8 & & 5 & 13 \\
\hline
\end{tabular}


The mean operation and fluoroscopy time and length of hospital stay are noted in Table 3. CT scans taken at postoperative 1st month showed residual stones in 6 of 13 (53\% success) horseshoe kidneys. Residual stone was detected in the patient with crossed renal ectopia and in 5 of 14 renal units with rotational anomalies (64\% success). $1.55 \mathrm{gr} / \mathrm{dL}$ decrease of hemoglobin $(\mathrm{Hb})$ was determined in patients with horseshoe kidney, $5.2 \mathrm{gr} / \mathrm{dL}$ in the patient with crossed renal ectopia and 0.9 $\mathrm{gr} / \mathrm{dL}$ in those with rotational renal anomalies. After discharge, 3 patients were hospitalized again; one with horseshoe kidney due to fever, one with crossed renal ectopia due to fever and recurrent hematuria, and one with rotational anomaly due to fever. The patient with recurrent hematuria was diagnosed with arteriovenous (AV) fistula and treated with superselective embolization. Colon injury was developed in a patient with rotational anomaly and the patient was treated conservatively. None of the patients developed sepsis and required any post-

Table 2. Access details

\begin{tabular}{|c|c|c|c|c|}
\hline Renal anomaly & $\begin{array}{l}\text { Horseshoe } \\
\text { kidney }\end{array}$ & $\begin{array}{l}\text { Crossed } \\
\text { renal } \\
\text { ectopia }\end{array}$ & $\begin{array}{l}\text { Rotational } \\
\text { anomaly }\end{array}$ & Total \\
\hline \multicolumn{5}{|c|}{ Number of access } \\
\hline Single & 10 & 1 & 10 & 21 \\
\hline Double & 3 & & 4 & 7 \\
\hline \multicolumn{5}{|l|}{ Access place } \\
\hline Upper calyx & 13 & & 6 & 19 \\
\hline Mid-calyx & 3 & 1 & 9 & 13 \\
\hline Lower calyx & & & 3 & 3 \\
\hline \multicolumn{5}{|l|}{ Access type } \\
\hline Intercostal & 5 & & 2 & 7 \\
\hline Subcostal & 11 & 1 & 16 & 28 \\
\hline
\end{tabular}

Table 3. Peroperative data and complications

\begin{tabular}{lllll}
\hline Renal anomaly & $\begin{array}{l}\text { Horseshoe } \\
\text { kidney }\end{array}$ & $\begin{array}{l}\text { Crossed } \\
\text { renal } \\
\text { ectopia }\end{array}$ & $\begin{array}{l}\text { Rotational } \\
\text { anomaly }\end{array}$ & Total \\
\hline $\begin{array}{l}\text { Mean operation } \\
\text { time (min.) }\end{array}$ & 120 & 65 & 120 & $109( \pm 11.0)$ \\
$\begin{array}{l}\text { Mean scopy time } \\
\text { (sec.) }\end{array}$ & 120 & 65 & 93 & $191( \pm 48.4)$ \\
$\begin{array}{l}\text { Length of hospital } \\
\text { stay (day) }\end{array}$ & 2 & 11 & 2 & 3 \\
$\begin{array}{l}\text { Success rate } \\
\begin{array}{l}\text { Postoperative } \\
\text { hemoglobin } \\
\text { decrease gr/dL }\end{array}\end{array}$ & 1.55 & 5.2 & 0.9 & 1.77 \\
Complication rates & & $0(0 \%)$ & $9(64 \%)$ & $16(57 \%)$ \\
Fever & 1 & 1 & 1 & 3 \\
AV fistula & & 1 & & 1 \\
Colon injury & & & 1 & 1 \\
\hline AV: Arteriovenous & & & & \\
\hline
\end{tabular}

operative intensive care (Table 3).

\section{Discussion}

Anomalies of fusion are the most common type among renal anomalies and horseshoe kidney is the most common type of fusion anomalies. It occurs in about 1/400 live births in the general population (2).

The final position of the adult kidney in the renal fossa is defined as the positioning of the kidney with an orientation of the renal calyces to outwards (the lateral) and the renal pelvis to inwards (the medial). When this positioning is not complete, then it is called malrotation. One autopsy series reported 1 in 939 cases $(2,3)$.

Crossed fused renal ectopia refers to an anomaly that the kidney is located on the opposite side where its ureter inserts into the bladder. This type is divided into two groups as fused or unfused and also into sub-grubs among themselves according to the form of the anomaly. Its incidence is generally estimated to be 1 in 1.000 live births $(2,4)$.

In patients with renal abnormalities, urinary stasis and infection due to abnormal localization of the renal pelvis and ureter as well as abnormal vascularization lead to stone formation (2).

Technically, PNL operation in a kidney with anomaly is a surgical application that creates concern for urologists. The main factors of difficulty include selecting the appropriate calyx and a suitable angulation for the access and operation within an unusual pelvicalyceal system. Its abnormal relationship with the surrounding organs and its abnormal vascularization, yet requiring abnormal angulation in accessing an abnormal pelvicalyceal, may increase the risk of injury in the surrounding organs and major veins. Most of the horseshoe kidneys reside lower in the abdomen than normal kidneys and intercostal accesses to reach upper- or mid-calyces are needed less than in normal kidneys. For the most reliable access to a horseshoe kidney, the upper calyx group, particularly far posterior and medial calyces should be preferred. Lower pole access is not recommended because the lower calyx group is located medially and anteriorly and in close proximity to the main vessels (5). In our cases, 5 of 16 accesses were intercostal and complications such as pneumothorax and hidrotorax and any pulmonary complications were not seen in any of our patients (6). Abnormal anatomic relationships of the abnormal kidney with the surrounding organs should always be kept in mind by the surgeon. Additionally, in our cases with rotation anomaly, the incidence of injuries to the adjacent organs such as the colon was relatively higher than in normal kidneys. This occurs as a result of incomplete development of the lateroconal fascia of the retrorenal colon and failure of the kidney to attain the 
place where it should be and its replacement by colon instead (7). Radio-anatomical evaluation by noncontrast abdominal CT imaging is recommended for all patients in order to prevent possible injury to the adjacent organs (8). The management in a possible colon injury includes withdrawing the nephrostomy slightly to provide it to serve as a drain for the injured region, placing a ureteral stent, and initiating parenteral antibiotherapy as a conservative approach (7). In the group with rotation anomaly, one patient had a colon injury and was treated conservatively. Another handicap originates from abnormal placement of renal vessels, which can result in injury to major vessels, AV fistula and pseudoaneurysms. Only one of our patients experienced vascular injury and this resulted in an AV fistula and treated successfully with superselective embolisation.

In a study of 52 renal anomalies including 31 horseshoes kidneys, 4 crossed ectopia, 7 rotation anomalies and 4 ectopic kidneys, Gupta et al. (9) reported that the mean hospital stay was 3.2 days and the average decrease in $\mathrm{Hb}$ was $1.4 \mathrm{~g} / \mathrm{dL}$. MosaviBahar et al. (10) reported their own PNL series performed in 7 horseshoes, 5 rotation anomalies, 3 ectopic kidneys and noted length of hospital stay of 3 days and $1.7 \mathrm{~g} / \mathrm{dL}$ decrease of $\mathrm{Hb}$. The average hospital stay was 3 days and average decrease of $\mathrm{Hb}$ was $1.7 \mathrm{~g} / \mathrm{dL}$ in our study, which is similar to the literature.

Gupta et al. (9) reported a success rate of $86 \%$ in the first attempt. The success rate was evaluated by using spot graphics in their study. The success rate in our study was $57 \%$. Stone-free status was assessed by abdominopelvic CT in our study so this may explain the difference between success rates.

\section{Study Limitations}

The main limitations of the study include its retrospective design, the fact that surgeries were not performed by the same surgeon, and the relatively low number of patients.

\section{Conclusion}

Patients with renal malformation can be treated with PNL safely and effectively.

\section{Ethics}

Ethics Committee Approval: Retrospective study.
Informed Consent: Consent form was filled out by all participants.

Peer-review: Externally peer-reviewed.

\section{Authorship Contributions}

Surgical and Medical Practices: T.S., Concept: C.S.I., Design: M.Y., Data Collection or Processing: B.E., H.T., Analysis or Interpretation: H.B., Y.Ö.I., Literature Search: M.K., Writing: T.S., C.S.i.

Conflict of Interest: No conflict of interest was declared by the authors.

Financial Disclosure: The authors declared that this study received no financial support.

\section{References}

1. Türk C, Petřík A, Sarica K, Seitz C, Skolarikos A, Straub M, Knoll T. EAU Guidelines on Diagnosis and Conservative Management of Urolithiasis. Eur Urol 2016;69:468-474.

2. Bauer S. Anomalies of the upper urinary tract. In: Walsh PC, Retic AB, 118 Vaughan E. Campbell's Urology, 8th ed. Philadelphia, Elsevier Saunders, 2002.

3. Binbay M, Istanbulluoglu O, Sofikerim M, Beytur A, Skolarikos A, Akman $T$ Huri E, Ozturk B, Kural AR, Muslumanoglu AY. Effect of Simple Malrotation on Percutaneous Nephrolithotomy: A Matched Pair Multicenter analysis. J Urol 2011;185:1737-1741.

4. Siegel YI, Lingeman JE. Percutaneous Transilial Access for Stone Removal in Crossed Fused Renal Ectopia. Urology 1993;42:82-85.

5. Raj GV, Auge BK, Weizer AZ, Denstedt JD, Watterson JD, Beiko DT, Assimos DG, Preminger GM. Percutaneous Management of Calculi with in Horshoes Kidneys. J Urol 2003;170:48-51.

6. Shokeir AA, El-Nahas AR, Shoma AM, Eraky I, El-Kenawy M, Mokhtar A, El-Kappany H. Percutaneous Nephrolithotomy in Treatment of Large Stones with in Horseshoe Kidneys. Urology 2004;64:426-429.

7. Skoog SJ, Reed MD, Gaudier FA Jr, Dunn NP. The Posterolateral and the Retrorenal Colon: Implication in Percutaneous Stone Extraction. J Urol 1985;134:110-112.

8. Saçak V, Demiray $M$, Özkan $S$, Toktaş MG, Ünlüer SE, Küçükpolat S. Our Experience on Percutaneous Nephrolithotomy in Horseshoe Kidneys. Istanbul Med J 2011;12:25-29.

9. Gupta NP, Mishra S, Seth A, Anand A. Percutaneous Nephrolithotomy in Abnormal kidneys: Single-Center Experience. Urology 2009;73:710-714.

10. Mosavi-Bahar SH, Amirzargar MA, Rahnavardi M, Moghaddam SM, Babbolhavaeji $\mathrm{H}$, Amirhasani S. Percutaneous Nephrolithotomy in patient with Kidney Malformations. J Endourol 2007;21:520-524. 